\title{
Wittgenstein, Ramsey and British Pragmatism
}

\section{Mathieu Marion}

\section{OpenEdition}

\section{Journals}

Electronic version

URL: http://journals.openedition.org/ejpap/720

DOI: 10.4000/ejpap.720

ISSN: 2036-4091

\section{Publisher}

Associazione Pragma

\section{Electronic reference}

Mathieu Marion, «Wittgenstein, Ramsey and British Pragmatism », European Journal of Pragmatism and American Philosophy [Online], IV-2 | 2012, Online since 24 December 2012, connection on 01 May 2019. URL : http://journals.openedition.org/ejpap/720 ; DOI : 10.4000/ejpap.720

This text was automatically generated on 1 May 2019.

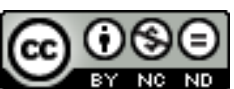

Author retains copyright and grants the European Journal of Pragmatism and American Philosophy right of first publication with the work simultaneously licensed under a Creative Commons AttributionNonCommercial-NoDerivatives 4.0 International License. 


\title{
Wittgenstein, Ramsey and British Pragmatism
}

\author{
Mathieu Marion
}

\section{AUTHOR'S NOTE}

In writing this paper, I made use of the draft of an earlier paper, "Ramsey as an Inferentialist," delivered at the Third Meeting on Pragmatism: Agency, Inference and the Origins of Analytic Philosophy in Granada, Spain in the spring 2006, organized by María J. Frápolli. I wish to thank the participants for their comments and acknowledge my debt to discussions with Nils-Eric Sahlin and François Latraverse for discussions over the years on the topic of this paper.

\section{Assessing Ramsey's Impact on Wittgenstein}

1 One may establish links between Wittgenstein and pragmatism in an abstract albeit superficial way à la Rorty, ${ }^{1}$ or one may try and establish them contextually, i.e., in terms of what historical evidence about Wittgenstein allows us to infer. I propose to do here the latter. Historical links would run either from Wittgenstein to the pragmatist tradition or from the pragmatist tradition to Wittgenstein. I choose to investigate links of the latter type, hoping that the connections uncovered actually help us to deepen our understanding of Wittgenstein's philosophy, albeit on some limited points. There is to my knowledge no discussion of C.S. Peirce in Wittgenstein's writings, only a reference en passant in a conversation by Rhus Rhees, ${ }^{2}$ which remains unpublished (it is at all events of peripheral interest), and, although there is quite a lot of discussion of William James, it is perhaps focused on topics, e.g., psychology and religious experience, that are not so specific to 'pragmatism.' If at first blush the idea of direct links seems not so promising - I do not wish, however, to say that it is not - perhaps the role of intermediaries is worth investigating, and this is what I shall do, focusing on 'British pragmatism,' and 
F. P. Ramsey in particular. The expression 'British pragmatism' was indeed coined by NilsEric Sahlin to characterize Ramsey's philosophy, ${ }^{3}$ and I shall extend it here to an heterogeneous group that includes, alongside him, C. K. Ogden and Bertrand Russell - a fuller picture should also include the more marginal figures of F. C. Schiller and Victoria Welby. ${ }^{4}$ The presence of Russell might strike one as odd even in such a miscellaneous list, but one should recall the equally odd remark at the end of Ramsey's "Facts and Propositions," to which I shall come back:

My pragmatism is derived from Mr Russell. ${ }^{5}$

2 At all events, the focus of this paper will be Ramsey, and what manner of pragmatist thinking he might have imparted in Wittgenstein. I shall therefore spend most of the paper explaining in what sense Ramsey may reasonably be said to be a pragmatist, and will in the last section explain how his critique in the late 1920s might have imparted a key pragmatist idea in Wittgenstein. ${ }^{6}$

3 In order to forestall any misunderstanding, I should state plainly that I do not believe Ramsey to be the chief inspirer of Wittgenstein's later philosophy, my aim is much more modest; it is simply to try and shed light on one pragmatist idea that might have been imparted by Ramsey - how important it may be in our overall account of the development of Wittgenstein's thought, I leave to others. There are certainly other topics on which the impact of Ramsey is more readily identifiable. For example, G. H. von Wright and Nils-Eric Sahlins have shown how much Wittgenstein's remarks on probability after 1929 owe to Ramsey. ${ }^{7}$ (To begin with, he corrected during his visit in 1923 a mistake in the first edition of the Tractatus. $)^{8}$ Perhaps more to the point, Wittgenstein's later remarks on truth should also be investigated, not in terms of a 'redundancy' theory but in terms of Ramsey's pragmatism.

Still, to argue for anything remotely like an 'influence' on Wittgenstein is bound to be controversial because of the habit of using Wittgenstein to pounce on philosophers he was acquainted with - Ramsey being here one of the prime targets alongside Frege, Russell, and Carnap - as opposed to aiming at a less brutal but potentially more fruitful appraisal of their intellectual relation, ${ }^{9}$ but also because, as we shall see presently, the textual evidence can easily be mishandled.

5 One should first recall some facts. ${ }^{10}$ Ramsey first heard about Wittgenstein when an undergraduate at Cambridge (1920-23), when at the age of 18, he translated Wittgenstein's Logisch-philosophische Abhandlungen into English - this is commonly known as the 'Ogden translation. ${ }^{11}$ Ramsey went twice to Austria, in September 1923, for the purpose of discussions with Wittgenstein, whom he saw for a fortnight in Puchberg (where he was a school teacher), and in March 1924, when he underwent a psychoanalysis with Theodor Reik in Vienna, lasting six months. During his stay, Ramsey only spend two week-ends with Wittgenstein, again at Puchberg. The contrast between the two occasions is striking: after his first meeting Wittgenstein, Ramsey wrote "I use to think Moore a great man but besides W!," ${ }^{12}$ while on his second visit in 1924, he wrote back: "He is no good for my work." ${ }^{13}$ As it turns out, however, on that second occasion Ramsey was himself absorbed in his psychoanalysis and hardly capable of philosophical work. This is again in contrast with the first visit, when Ramsey discussed the content of the Tractatus with Wittgenstein and tried to pick his brain for ideas on how to fix Principia Mathematica. This last was a failure, as Wittgenstein thought Principia Mathematica "so wrong that a new edition would be futile," ${ }^{14}$ but their discussion of the Tractatus led to a remarkably astute review of the book by Ramsey in the October issue of Mind. ${ }^{15}$ 
6 Today, a promising young undergraduate such as Ramsey would be warned to stay away from Wittgenstein, but this was not the mentality back then, and Ramsey wanted to learn from Wittgenstein ideas that he would use for his own independent work. ${ }^{16}$ He pushed Wittgenstein's ideas in three directions: first, he used Wittgenstein's idea that names of properties and relations may occur in elementary propositions to develop a critique of the distinction between universals and particulars in "Universals," secondly, he used Wittgenstein's conception of logic in his analysis of belief and truth, in "Facts and Propositions" and "Truth and Probability," and thirdly, he tried to renovate Russell's logicism with help of ideas from the Tractatus. Only the second of these directions will be the focus of this paper.

Ramsey was to meet again Wittgenstein briefly in 1925 at Keynes' in Sussex (on the occasion of the latter's marriage to Lydia); they apparently bitterly quarreled but this was about psychoanalysis, not philosophy. They also exchanged a pair of letters on identity through the intermediary of Schlick in 1927, with Wittgenstein raising objections to Ramsey's definition of identity in his 1925 paper "The Foundations of Mathematics"; again we see here how divergent their views on the foundations of mathematics were. ${ }^{17}$ Nevertheless, part of Wittgenstein's intention when coming to Cambridge in January 1929 was to discuss philosophy with Ramsey, and they apparently met on a regular basis until the latter's untimely death a year later, in January 1930, at the age of 27. Wittgenstein, who was deeply moved by his death, ${ }^{18}$ had an ambivalent attitude towards their discussions: in 1929, he described them as "energic sport" and conducted in "good spirit," with "something erotic and chivalrous about them," ${ }^{19}$ but a year later he reminisced that although he had a "certain awe" of Ramsey, the conversations "in the course of time [...] did not go well"; he thought Ramsey had an "ugly mind," and that repulsed him. ${ }^{20}$

There are many traces of these discussions in Ramsey's posthumous papers, including a recently published set of remarks presumably dictated to Ramsey by Wittgenstein from his own manuscript, MS 106, that may have served as a basis for his paper at the Joint session in Nottingham in $1929 .{ }^{21}$ There are also a few remarks in Wittgenstein's Nachlaß referring to these conversations, among the many comments on Ramsey, more often than not negative, that are mostly referring to his printed papers.

In order to assess the possible impact of these conversations and of Ramsey's ideas on Wittgenstein, one should, for obvious exegetical reasons, stick as much as possible to texts from 1929. As I said, however, it is very easy to bungle one's interpretation; one obvious but common mistake is to appeal to Wittgenstein's later views in order to contrast them with Ramsey's. ${ }^{22}$ That is presupposing that Wittgenstein had them in mind in 1929 ready to use to rebut Ramsey, which is plainly false, and, supposing more rightly that they occurred to him later, that this happened independently of any impact from Ramsey: if one's task is to assess the latter, then the procedure is perfectly circular. Thus, it is better to assume that in 1929 Wittgenstein hardly did any thinking on his own for years and that he was therefore barely able to articulate in clear terms a critique of his Tractatus, while Ramsey had already articulated an astute one in his 1923 review and moved further along since.

One should also beware of the fact that Ramsey's views evolved in the last two years of his life, i.e., in 1928-29: it would thus be mistaken to assess the result of these conversations by helping oneself without proper care to views expressed by Ramsey in papers published in previous years. Indeed, Ramsey's major philosophy papers were all published in 1925-26: "Universal" and "The Foundations of Mathematics" in 1925, "Mathematical 
Logic" in 1926, to which one may add the posthumously published "Truth and Probability" written in the same year, and "Facts and Propositions" in 1927. His tragic death in January 1930 meant that Ramsey could not complete any new philosophy papers reflecting his views for 1928-29, but some important manuscripts were published in 1931, as his 'last papers. ${ }^{23}$ There are important contrasts between the views expressed in these two sets of papers, and this paper revolves around one of them. Alas, there is no clear evidence that Wittgenstein read the 'last papers,' but it is clear that their content was known to him through his discussions with Ramsey, because after 1929 he has abandoned some views held in the Tractatus for reasons rather akin to Ramsey's own change of mind.

11 My point is thus that it is a sine qua non condition that one understands Ramsey's thought in terms inclusive of these 'last papers' in order the assess the impact of his discussions with Wittgenstein. In particular, one should first notice that almost all of Wittgenstein's remarks openly critical of Ramsey's views concern topics in the philosophy of mathematics, where they obviously did not see eye to eye. One obvious topic is infinity: Wittgenstein always stuck to the potential infinite while Ramsey adhered to an 'extensionalist' conception that admits of infinite totalities. But Ulrich Majer has shown that by 1929 Ramsey had already begun holding finitist views that are critical of his earlier stance in 'The Foundations of Mathematics' and 'Mathematical Logic,'24 and I have attempted in the past to show the relevance of these new views for our understanding of the development of Wittgenstein's philosophy of mathematics. ${ }^{25}$ Brian McGuinness' disagreed with what he perceived as the gist of this work:

Ulrich Majer and Mathieu Marion for example think Ramsey taught Wittgenstein to view mathematics in an intuitionist and even finitist way. [...] it seems to me that influence is not the right word: we might better remember Gilbert Ryle's reply when asked whether he had been influenced by Wittgenstein: "I learnt a lot from him." Now Wittgenstein clearly learnt a lot from Ramsey and came back to philosophy with a knowledge of the thought of Weyl, Brouwer and Hilbert that he would not have had otherwise. But he certainly did not adopt a position near intuitionism under Ramsey's influence - Ramsey's conversion (if such it was) occurred after their meeting in 1925 and Wittgenstein's enthusiasm for Brouwer did not result from but was the reason for going to the 1928 lecture. It was not a Cambridge product. ${ }^{26}$

12 McGuinness is certainly right about the fact that Wittgenstein was not 'influenced' by Ramsey. There are clear indications that, in 1929, they shared a common ground on a number of issues in the philosophy of mathematics, grounds that might justify labelling them as 'intuitionists' or 'finitists.' Although it is undeniable that Ramsey changed his mind, manuscripts show that he began to do so in 1928, before Wittgenstein's return to Cambridge. ${ }^{27}$ This being said, McGuinness is quite right in saying that, if Wittgenstein's views were indeed close to those of Brouwer, it was not as a result of Ramsey's influence: I have argued elsewhere that, in order to understand his stance towards Brouwer's intuitionism, one ought to look at what he wrote on mathematics in the Tractatus, where his view are already remarkably close to Brouwer's; ${ }^{28}$ this also serves to understand his rejection of Ramsey's earlier views on foundations. For that reason, it seems also right for McGuinness to deny any 'influence.' I should be sorry if, for my part, I spoke in such terms; it is not possible and to some extend pointless to decide who influenced whom. But it seems wrong merely to reduce for that reason the role of Ramsey to that of having pointed out to Wittgenstein the existence of a number of papers by Hermann Weyl and others expressing alternative views on the foundations of mathematics. 
More importantly, Wittgenstein kept coming back in his manuscripts to Ramsey's earlier 'extensionalist' views on identity and infinity in order to criticize them, thereby giving the impression that he actually took nothing from Ramsey - this is the view taken, for example, by Wolfgang Kienzler in his careful study of Wittgenstein's Wende. ${ }^{29}$ (Wittgenstein's oracular style that make some of his statement appearing as if conjured from nowhere else than his mind is also likely to mislead in this respect - I shall give an example of this below.) In making a proper assessment of Ramsey's impact, these passages should not only be dismissed precisely because they cannot refer back to Ramsey's views in 1929, and therefore fail to explain anything about their exchanges during that year, but also, in the context of this paper, because they deal with issues in the foundations of mathematics, where no pragmatist import could ever be detected. So we better drop the issue, once these words of caution are expressed.

That his discussions with Ramsey had an effect on Wittgenstein's thought is at the very least acknowledged in no uncertain terms in the preface to Philosophical Investigations:

For since I began to occupy myself with philosophy again, sixteen years ago, I could not but recognize grave mistakes in what I set out in that first book [the Tractatus Logico-Philosophicus, M.M.]. I was helped to realize these mistakes - to a degree which I myself am hardly able to estimate - by the criticism which my ideas encountered from Frank Ramsey, with whom I discussed them in innumerable conversations during the last two years of his life. ${ }^{30}$ Even more than to this - always powerful and assured - criticism I am indebted to that which a teacher of this university, Mr. P. Sraffa, for many years unceasingly applied to my thoughts. It is to this stimulus that I owe the most fruitful ideas of this book. ${ }^{31}$

Even if we are to follow Wittgenstein and attribute to Sraffa a more significant role, the bottom line remains that Wittgenstein acknowledged a debt to Ramsey and this simply needs to be elucidated - there is no going around it.

It is true that Wittgenstein seems to imply in his preface that Ramsey's input was merely negative, and achieved only through criticism of his older ideas, but a narrow reading that would deny any positive contribution cannot be wholly right, if only because the idea of a purely negative critique, short of a Socratic elenchus, is hard to make sense of. The following pair of quotations support this point. Ramsey is mentioned only once more in Philosophical Investigations:

F. P. Ramsey once emphasized in conversation with me that logic was a 'normative science.' I do not know exactly what idea he had in mind, but it was doubtless closely related to one that dawned on me only later: namely, that in philosophy we often compare the use of words with games, calculi with fixed rules, but cannot say that someone who is using language must be playing such a game. - But if someone says that our languages only approximate to such a calculi, he is standing on the very brink of a misunderstanding. For then it may look as if what we were talking about in logic were an ideal language. As if our logic were, so to speak, a logic for a vacuum. - Whereas logic does not treat of language -or of thought- in the sense in which a natural science treats a natural phenomenon, and the most that can be said is that we construct ideal languages. ${ }^{32}$

One may usefully compare this with remarks jotted down by Ramsey in September 1929:

Logic, i.e., the laws of thought, is according to $\mathrm{L}($ (udwig)) W((ittgenstein)) a consequence of analytic psychology. Es liegt im Begriff des Denkens dass man $p . \approx p$ nicht denken kann.

Aber dieser Begriff des Denkens ist keiner naturwissenschaftlicher.

Die Psychologie von auswärts kann diesen Begriff gar nicht Benützen.

It is just like chess; in a game of chess you can't have 10 white queens on the board, 
the emphasis is on chess. You can put them on the board if you like but that isn't chess.

So also in thought you cannot have $p . \approx p$; you can write that if you like but it will not be thought.

But I think we can define chess.

Can we define thought, and is there any such thing? What are its rules and who plays it? It isn't common, it is something to which we approximate by getting our language clear.

"All our everyday prop((osition))s are in order" is absolutely false, and shows the absurdity of interpreting logic as part of natural science. ${ }^{33}$

It is worth noting that none of the German sentences in this passage are to be found in Wittgenstein's Nachlaß, it is thus reasonable that they may have come from a conversation with Wittgenstein. But Ramsey is also referring here to views harking back to the Tractatus: the last sentence contains a quotation from 5.5563, while the idea that one cannot think a contradiction is related to the impossibility of "judging a nonsense" in 5.5422. And, as Wittgenstein himself recognized above, Ramsey's standpoint is the right one: when he writes that logic is not a natural science, Wittgenstein is expressing an idea he clearly got from Ramsey, not merely from having been effectively criticized. The following will have a lot to do with this positive contribution.

\section{Ramsey and British Pragmatism}

Ramsey's gave a concise expression of his own pragmatism in the last sentences of 'Facts and Propositions':

In conclusion, I must emphasize my indebtedness to Mr Wittgenstein, from whom my view of logic is derived. Everything that I have said is due to him, except the parts which have a pragmatist tendency, which seem to me to be needed in order to fill up a gap in his system. [...] My pragmatism is derived from Mr Russell; and is, of course, very vague and undeveloped. The essence of pragmatism I take to be this, that the meaning of a sentence is to be defined by reference to the actions to which asserting it would lead, or, more vaguely still, by its possible causes and effects. (Ramsey 1990: 51)

This passage already gives us two clues. First, that Ramsey had identified what he believed to be a gap in the system of Wittgenstein's Tractatus and that he believed his pragmatism would fill it. Secondly, as already mentioned, Ramsey points to Russell's pragmatism as the source of his own pragmatism.

21 As for the first clue, what would that gap be? My suggestion is that we look at Ramsey's review of the Tractatus and his critique of Wittgenstein's analysis at 5.542 of 'A believes $p$ ' as ' ' $p$ ' says $p$." Ramsey's qualms had to do with the fact that he rejected Wittgenstein's grounding of the notion of 'truth-possibility' on the notion of 'possibility of existence or non-existence of states of affairs,' in 4.3:

4.3 - Truth possibilities of elementary propositions mean possibilities of existence or non-existence of states of affairs. ${ }^{34}$

Recall here that 'truth-possibilities' allow one to form the usual truth-tables (4.31), given that truth possibilities of elementary propositions are "the conditions of the truth and falsity of propositions" (4.41), and that

4.4 - A proposition is an expression of agreement and disagreement with truthpossibilities possibilities of elementary propositions. 


$$
\text { and } q \text { ' or }
$$

$$
\text { (FTTT) }(p, q)
$$

is the proposition that expresses disagreement with the first truth-possibility and agreement for the next three. What this means is that a proposition is identified with a mapping from truth-possibilities of its elementary propositions to truth-values. In the case at hand, the first truth-possibility, $p$ and $q$ being true, is mapped onto falsehood, the next three onto truth. But Wittgenstein notoriously grounds, as we just saw, 'truthpossibility' on the notion of 'possibility of existence or non-existence of states of affairs,' and these depend on what objects there are in the world and their form. This ontological grounding is the reason for my calling Wittgenstein's theory 'static,' and my point here is that Ramsey is going to replace it by a more 'dynamic' pragmatic theory. He voiced first his criticisms in his review:

[Wittgenstein's theory] enables us to substitute for ' $p$ ' says $p$. ." ' $p$ ' expresses agreement with these truth-possibilities and disagreement with these others," but the latter formulation cannot be regarded as an ultimate analysis of the former, and it is not at all clear how its further analysis proceeds. ${ }^{35}$

He then went on criticizing Wittgenstein's suggestion at 5.542 that “ " $p$ ' says $p$ " is a coordination of facts by means of coordination of their objects:

But this account is incomplete because the sense is not completely determined by the objects which occur in it; nor is the propositional sign completely constituted by the names which occur in it, for in it there may also be logical constants which are not co-ordinated with objects and complete the determination of the sense in a way which is left obscure. ${ }^{36}$

In 'Facts and Propositions,' he also rejected this theory with a powerful argument, namely that the meaning-explanations in the Tractatus are relative to a language:

We supposed above that the meaning of the names in our thinker's language might be really complex, so that what was to him an atomic sentence might after translation into a more refined language appear as nothing of the sort. ${ }^{37}$

And he pointed out that the presupposition that truth-possibilities are all possible clashed with Wittgenstein's assumption that 'This is both blue and red' is contradictory this being the notorious color-incompatibility problem, one of the first flaws that Wittgenstein tried to repair in 1929, with well-known consequences. Ramsey nails the point with the analogy of chess:

This assumption might perhaps be compared to the assumption that the chessmen are not so strongly magnetized as to render some positions on the board mechanically impossible, so that we need only consider the restrictions imposed by the rules of the game, and can disregard any others which might conceivably arise from the physical constitution of men. ${ }^{38}$

To see what Ramsey's solution was, we need to deal first with the second of the above clues. Richard Braithwaite, who was probably Ramsey's closest friend, described Cambridge through the early post-war years in these terms:

In 1919 and for the next few years philosophic thought in Cambridge was dominated by the work of Russell [...] the books and articles in which he developed his ever-changing philosophy were devoured and formed the subject of detailed commentary and criticism in the lectures of G. E. Moore and W. E. Johnson. (ob. $1931)^{39}$ 
During those years, Russell published "On Propositions: What they Are and How they Mean" (1919), participated with H. H. Joachim and F. S. C. Schiller in a symposium, in Mind on "The Meaning of 'Meaning" (1920), which generated a debate in subsequent issues, and, finally, Analysis of Mind (1921). In these, Russell went on developing (and abandoning) what may be called a 'causal theory of meaning' which was indeed central to discussions in Cambridge, as C. K. Ogden and I. A. Richard would go on proposing a very similar theory in The Meaning of Meaning (1923), and, as we shall see, both theories were to form part the background to Ramsey's "Facts and Propositions." As a matter of fact, when Ramsey spoke above of Russell's pragmatism, he was referring to this theory. ${ }^{40}$ Wittgenstein, it is well known, was also to read carefully and criticize Russell's Analysis of Mind in chapter III of Philosophical Remarks. ${ }^{41}$

In "On Propositions: What they Are and What they Mean," Russell expressed for the first time the 'causal theory' in those terms:

According to this theory - for which I cannot make any author responsible - there is no single occurrence which can be described as "believing a proposition," but belief simply consists in causal efficacy. Some ideas move us to action, other do not; those that do so move us are said to be believed..$^{42}$

31 It is interesting to note that Russell does not attribute this theory to anyone, he simply claims that it is implicitly assumed by James, the only pragmatist whose writings he really knew at that stage. As it turns out, Russell rejected it but in Analysis of Mind, he presents his 'causal theory' in quasi-pragmatic terms:

We may say that a person understand a word when (a) suitable circumstances makes him use it, (b) the hearing of it causes suitable behavior in him. ${ }^{43}$

The relation of a word to its meaning is of the nature of a causal law governing our use of the word and our actions when we hear it used. ${ }^{44}$

C. K. Ogden \& I. A. Richards were to propound sensibly the same theory in The Meaning of Meaning that Ramsey reviewed in Mind. ${ }^{45}$ Incidentally, one should note Russell's claim in those pages that understanding is, to use Gilbert Ryle's words, a 'knowing how,' and not a 'knowing that':

It is not necessary, in order that a man should "understand" a word, that he should "know what it means," in the sense of being able to say "this word means so-andso." [...] Understanding language is more like understanding cricket: it is a matter of habits, acquired in oneself and rightly presumed in others. To say that a word has a meaning is not to say that those who the word correctly have ever thoguht out what the meaning is: the use of the word comes first, and the meaning is to be distilled out of it by observation and analysis. ${ }^{46}$

This is, I believe, the reason why Ramsey spoke of Russell's pragmatism in the opening quotation of this section.

It would be wrong, however, to conflate Ramsey's theory in 'Facts and Propositions' with these views of Russell and Ogden \& Richards, because Ramsey's theory is more truly pragmatic and because, on the key point which is his solution the problem note above in the Tractatus, there is no antecedent in Russell and Ogden \& Richards. As a matter of fact, Wittgenstein criticized these last as follows:

The essential difference between the picture conception and the conception of Russell, Ogden and Richards, is that it regards recognition as seeing an internal relation, whereas in their view this is an external relation.

That is to say, for me, there are only two things involved in the fact that a thought is true, i.e. the thought and the fact; whereas for Russell there are three, i.e. thought, fact and a third event which, if it occurs, is just recognition. [...] 
The causal connection between speech and action is an external relation, whereas we need an internal one. ${ }^{47}$

This critique does not apply to Ramsey's "Facts and Propositions," as we shall see, since he does not introduce any third element in modifying the 'picture conception.'

Ramsey relies indeed here directly on Peirce, whose writings he probably discovered through C. K. Ogden \& I. A. Richards' The Meaning of Meaning, ${ }^{48}$ published in 1923, which is also the year of the publication of Chance, Love and Logic, quoted by Ramsey in his writings. When he wrote in the above-quoted passage that

the meaning of a sentence is to be defined by reference to the actions to which asserting it would lead [...]

Ramsey merely expressed an idea one that one can already find in Peirce, who wrote in "The Fixation of Belief" (1877):

our beliefs should be such as may truly guide our actions so as to satisfy our desires. 49

Furthermore, in "How to Make our Ideas Clear" (1878), Peirce claimed that "the whole function of thought is to produce habits of action" and that to make explicit the meaning of a belief

we have [...] simply to determine what habits it produces, for what a thing means is simply what habits its involves. ${ }^{50}$

These passages show that Peirce conceived of beliefs as habits and a guides to action. ${ }^{51}$ These ideas are to be found almost verbatim in Ramsey's 'last papers':

All belief involves habit. ${ }^{52}$

The ultimate purpose of thought is to guide our action..$^{53}$

It belongs to the essence of any belief that we deduce from it, and act on it in a

certain way. ${ }^{54}$

What these snippets show is a direct influence of Peirce's pragmatism on Ramsey. This influence can be felt in two crucial stages, first in Ramsey's use of these ideas to rectify in 'Facts and Propositions' the above blemish he found in Wittgenstein's Tractatus, and secondly in the 'last papers.'

4 Ramsey's solution to the problems he raised in his review of the Tractatus, discussed above, consisted simply in identifying a belief in a proposition with the set of truthpossibilities under which it is true:

Thus, to believe $p$ or $q$ is to express agreement with the possibilities $p$ true and $q$ true, $p$ false and $q$ true, $p$ true and $q$ false, and disagreement with the remaining possibility $p$ false and $q$ false. To say that feeling belief towards a sentence expresses such an attitude is to say that it has certain causal properties which vary with the attitude, i.e. with which possibilities are knocked out and which, so to speak, are still left in. Very roughly the thinker will act in disregard of the possibilities rejected, but how to explain this accurately I do not know..$^{55}$

In other words, according to Ramsey, who adopts here the pragmatist point of view, for someone to believe in ' $p$ 閭 $q$ ' means to "act in disregard of the possibilities rejected." 56 This identification of belief with act is what I called the 'dynamic' element, with which Ramsey corrects the 'static' conception of the Tractatus. (One also should note here, in relation to Wittgenstein's critique of Russell and Ogden \& Richards quoted above that Ramsey did not introduce a new element.)

Thus both Russell's and Peirce's conceptions need to be taken into account in understanding Ramsey's pragmatism and the manner in which he sought to rectify the 
Tractatus. For the second stage of this influence, one has to bear in mind that Ramsey's thought had evolved by 1929 - after all these last three quotations are from the 'last papers' - and one cannot simply refer back to the views in 'Facts and Propositions' and contrast them with Wittgenstein in order to emphasize the disagreements between the two philosophers. One needs instead to show how the pragmatist insights gained early evolved into the 'last philosophy' of Ramsey (hardly two years later), in order to make the right sort of comparison with Wittgenstein. This requires, however, that one provides a 'non standard' interpretation of Ramsey's philosophy. ${ }^{57}$ By this I mean the following. If we follow, for example, Christopher Hookway, both Peirce and Ramsey defend an account of belief which is 'representationalist' - this is not Hookway's term - because it combines two elements: representations, as they "display a logical structure which suits them for use in inference," and:

[...] representations that function as beliefs have a special role in the determination of action which makes it appropriate to regard them as embodying habits of action. 58

This might right as a portrayal of Peirce, who held general beliefs to be representations, but I think that this is not exactly true about the Ramsey of the 'last papers' for reasons that I shall present in the next section.

\section{Ramsey's 'Human Logic'}

My starting point will be what Colin Howson called Ramsey's 'big idea,' i.e., the idea that the laws of probability are rules of consistency for the distribution of partial beliefs..$^{59}$ Following the British tradition and Keynes in particular, Ramsey adhered to the view of logic as the 'science of rational thought,' i.e., the science that "tells men how they should think." ${ }^{60}$ (Another influence here might simply be Peirce's view of logic as 'self-control.') ${ }^{61}$ This is the view of logic as 'normative' that Wittgenstein mentioned in Philosophical Investigations, § 81, quoted above. Ramsey also used Peirce's distinction between 'explicative' and 'ampliative' arguments, ${ }^{62}$ to suggest that this 'science of rational thought,'

[...] must then fall very definitely into two parts: [...] we have the lesser logic, which is the logic of consistency; and the larger logic, which is the logic of discovery, or inductive logic. ${ }^{63}$

The 'larger' logic, Ramsey also called 'logic of truth,' so we can divide the subject into a 'logic of consistency' and a 'logic of truth.' The former contains what Ramsey called 'formal logic'; this is basically what we consider today as 'logic. ${ }^{16} \mathrm{His}$ 'big idea' was thus to have seen that the theory of subjective probability actually belongs to the 'logic of consistency,' as a generalization of formal logic. In order to do this, he re-described formal logic as the 'logic of consistency' for full or 'certain' beliefs of degree 0 or 1 and proposed to see his theory of subjective probability as generalization of this to partial beliefs, i.e., beliefs of degree from 0 to 1 . Therefore, the distinction between 'logic of consistency' and 'logic of truth' does not overlap the distinction between certain and partial beliefs:

What we have now to observe is that [the distinction between the logic of consistency and logic of truth] in no way coincides with the distinction between certain and partial beliefs; we have seen that there is a theory of consistency in partial beliefs just as much as of consistency in certain beliefs, although for various 
reasons the former is not so important as the latter. The theory of probability is in fact a generalization of formal logic [...]. ${ }^{65}$ Ramsey's paper, the Dutch Book Theorem. Following Patrick Suppes, ${ }^{66}$ one may distinguish within Ramsey's subjective probability theory between 'structure' and 'rationality' axioms. One of the rationality axioms is the well-known 'transitivity principle,' which states that, for all outcomes $a, b$ and $c$, if $a$ is preferred to $b$ and $b$ is preferred to $c$, then $a$ should be preferred to $c$. Ramsey commented on possible violations of this principle in the following terms:

Any definite set of degrees of belief which broke [the laws of probability] would be inconsistent in the sense that it violated the laws of preference between options, such as that preferability is a transitive asymmetrical relation, and that if is $\alpha$ preferable to $\beta, \beta$ for certain cannot be preferable to $\alpha$ if $p, \beta$ if not- $p$. If anyone's mental condition violated these laws, his choice would depend on the precise form in which the options were offered him, which would be absurd. He could have a book made against him by a cunning better and would then stand to lose in any event. (Ramsey 1990: 78)

With this remark, Ramsey stated without proof what is now known as the Dutch Book Theorem - a choice of betting quotients resulting in a certain loss being called by bookmakers a Dutch Book. The first explicit proof was given by Bruno de Finetti, ${ }^{67}$ in complete ignorance of Ramsey's work. The Dutch Book Theorem is often used as a justification for the axioms of subjective probability theory. A typical claim derived from it, made here by Donald Davidson, is that it shows that it is rational to act according to that theory:

Because the constraints are sharply stated, various things can be proven about the theory. The intuition that the constraints define an aspect of rationality, for example, can be backed by a proof that only someone whose acts are in accord with the theory is doing the best he can by his own lights: a Dutch book cannot be made against him. ${ }^{68}$

It is important at this juncture, especially since much has been made of Davidson's debt to Ramsey, to see the latter viewed the matter differently:

We find, therefore, that a precise account of the nature of partial belief reveals that the laws of probability are laws of consistency, an extension to partial beliefs of formal logic, the logic of consistency. They do not depend for their meaning on any degree of belief in a proposition being uniquely determined as the rational one; they merely distinguish those sets of beliefs which obey them as consistent ones. ${ }^{69}$

The thought is repeated a later on:

We found that the most generally accepted parts of logic, namely formal logic, mathematics and the calculus of probability are all concerned simply to ensure that our beliefs are not self-contradictory. We put before ourselves the standard of consistency and construct these elaborate rules to ensure its observance. ${ }^{70}$

It is crucial that one reads these passages very carefully. One should indeed notice that in these passages Ramsey merely claims that "the laws of probability are laws of consistency." There is no implication whatsoever in this passage that to be consistent is to be rational or that to violate the principle of transitivity is to be irrational. The words 'rational' or 'reasonable' are not used at all in that section, except, as a matter of fact, only when the contrary is claimed, i.e., when Ramsey says that the laws of probability "do not depend for their meaning on any degree of belief in a proposition being uniquely determined as the rational one" (my emphasis). This was a direct criticism of Keynes' 
views on probability, ${ }^{71}$ leading to the dismissal of his Principle of Indifference. ${ }^{72}$ Here too Ramsey avoided claims concerning rationality, while emphasizing consistency:

The Principle of Indifference can now be altogether dispensed with; we do not regard it as belonging to formal logic to say what should be a man's expectation of drawing a white or a black ball from an urn; his original expectations may within the limits of consistency be any he likes; all we have to point out is that if he has certain expectations he is bound in consistency to have certain others. This is simply bringing probability into line with ordinary formal logic, which does not criticize the premises but merely declares that certain conclusions are the only ones consistent with them. ${ }^{73}$

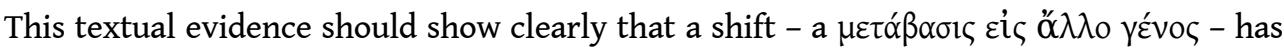
occurred, from Ramsey to Suppes and Davidson. That this shift is for the better or not is not what is at stake here, we merely need to ascertain what Ramsey's views were, and his point clearly was not that inconsistency must be considered irrational. The common view that Ramsey's theory is about "an actual human reasoner, like you and me, and not [about] some ideal reasoner"74 is also misleading in this respect. The basis for this view must be the opening paragraph of section 4 of "Truth and Probability," entitled "The Logic of Consistency":

We may agree that in some sense it is the business of logic to tell us what we ought to think; but the interpretation of this statement raises considerable difficulties. It may be said that we ought to think what is true, but in that sense we are told what to think by the whole of science and not merely by logic. Nor, in this sense, can any justification be found for partial belief; the ideally best thing is that we should have beliefs of degree 1 in all true propositions and beliefs of degree 0 in all false propositions. But this is too high a standard to expect of mortal men, and we must agree that some degree of doubt or even error may be humanly justified. ${ }^{75}$

The reference to 'mortal men' implies a contrast with God, so the idea here is that the 'ideal reasoner' is God, who can reason, given his infinite powers, in terms of full and certain beliefs that are also true. The point made later on in exactly those terms:

As has previously been remarked, the highest ideal would be always to have a true opinion and be certain of it; but this ideal is more suited to God than to man. ${ }^{76}$

It is not to be denied that subjective probability theory, as the logic of consistency for partial beliefs is, by contrast, about humans. It is trivially so. Nevertheless, I find the point misleading because the cognitive capacities of that 'actual human reasoner, like you and me' are left unspecified by such formulations and may very well be idealized to begin with and I think Ramsey did not conceive his 'logic of truth' in terms of such idealizations at all. In a nutshell, there is no discussion the passages above of the theory of subjective probability as providing an explanation of human actions but only as setting a 'standard of consistency' that we should observe and there is no indication either that Ramsey believed that the 'actual human reasoner, like you and me' has the cognitive capacities needed always to observe that 'standard.' But I should first say a few more things about the other part of the 'science of rational thought,' the 'logic of truth.'

As opposed to most supporters of subjective probability, Ramsey also believed in 'objective' or 'statistical' probability, which he called 'frequencies. ${ }^{77}$ The 'logic of truth' is in fact concerned with these: given the "standard of consistency," how do we adapt to 'frequencies'? As Ramsey would put it: "we want our beliefs to be consistent not merely with one another but also with facts." 78 As Ramsey reminds us, the human mind "works essentially according to general rules or habits," 79 and one wishes to evaluate such 'habits,' i.e., to find out whether the degree of belief an habit produces fits the 
frequencies or not, i.e., leads to truth or not. ${ }^{80}$ (This is why Ramsey spoke of a 'logic of discovery' and, in potentially misleading ways, of 'inductive logic.') ${ }^{81}$ Ramsey was thus hoping to provide through that procedure a justification for induction as a 'useful habit' so that one can agree that "to adopt it is reasonable." ${ }^{\text {2 }}$ In short, a belief is deemed 'reasonable' if it is obtained by a 'reliable' process. ${ }^{83}$

At this stage, however, Ramsey's 'logic of truth' threatens to evaporate into a 'reliabilist' program, which would fall prey to Goodman's Paradox ${ }^{84}$ But this issue is, again, tangential to my attempt at clarifying Ramsey's views, and I should emphasize instead another aspect of Ramsey's 'logic of truth,' which is better captured by another expression which he uses synonymously: 'human logic. ${ }^{85}$ Again, this expression is likely to mislead: for example, one might think that Ramsey had in mind an empirical description of how humans actually make choices. But Ramsey excluded such psychological considerations and wished to retain the normative character of logic, which "tells men how they should think," ${ }^{86}$ or "what it would be reasonable to believe." ${ }^{87}$ So Ramsey's overall classification should be as follows:

Ramsey's Classification

Logic as Science of Rational Thought
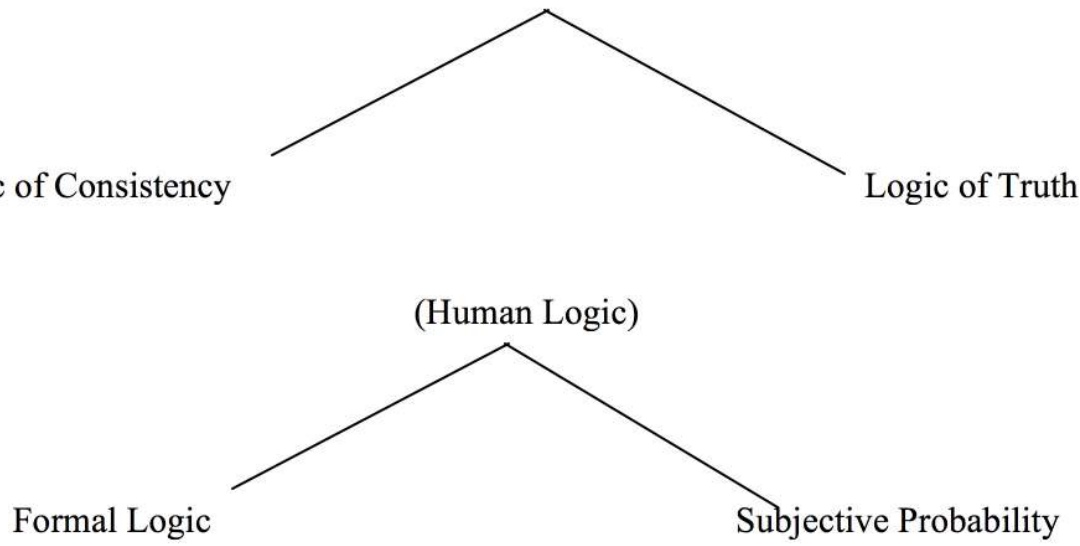

And the situation is nicely summed up in this passage from Keynes:

[Ramsey] was led to consider "human logic" as distinguished from "formal logic." Formal logic is concerned with nothing but the rules of consistent thought. But in addition to this we have certain "useful mental habits" for handling the material with which we are supplied by our perceptions and by our memory and perhaps in other ways, and so arriving at or towards truth; and the analysis of such habits is also a sort of logic. [...] in attempting to distinguish a "human" logic from formal logic on the one hand and descriptive psychology on the other, Ramsey may have been pointing the way to the next field of study when formal logic has been put into good order and its highly limited scope properly defined. ${ }^{88}$

As I said earlier, Ramsey did not present his theory of subjective probability as providing an explanation of human actions but only as setting a 'standard of consistency' that we should observe, and he did not give any indication that he assumed that we possess the cognitive capacities needed always to observe it. If anything, in his discussion of subjective probability theory, he pointed out an obvious obstacle to its applicability:

nothing has been said about degrees of belief when the number of alternatives is infinite. [...] I doubt if the mind is capable of contemplating more than a finite number of alternatives. ${ }^{89}$ 
Ramsey's view was that we do not have the cognitive capacities necessary always to observe the standards of consistency set out in both branches of the 'logic of consistency' and that it is precisely for that reason that he believed it necessary to add a further branch to the 'science of rational thought,' whose concerns are precisely with what it is 'reasonable' or 'rational' to believe, given that we do not have these capacities. In other words, there is nothing in what Ramsey says about 'human logic' that implies that he believed that it should be some sort of applied subjective probability theory, as it has more or less been implicitly taken to be since in the work of Jeffrey, Suppes, and Davidson. The shift to the modern view thus consists of the conflation of subjective probability theory and the 'logic of truth' or 'human logic.' Once we have understood what Ramsey's 'human logic' is truly about, we can then factor in the pragmatism he took on board via Russell, and we can thus begin to look at what he had to say about 'variable hypotheticals' in 1929, and what possible connexions there are with Wittgenstein had to say about 'hypotheses.'

\title{
4. Ramsey's Variable Hypotheticals and Wittgenstein's Hypotheses
}

60 My case will rest on the reading of two passages and on links with remarks found principally in one of the 'last papers,' "General Propositions and Causality." In the first passage, which deserves to be read carefully, Ramsey made plain that the "standard of consistency" set by the 'logic of consistency' is "not enough":

\begin{abstract}
this is obviously not enough; we want our beliefs to be consistent not merely with one another but also with the facts: nor is it even clear that consistency is always advantageous; it may well be better to be sometimes right than never right. Nor when we wish to be consistent are we always able to be: there are mathematical propositions whose truth or falsity cannot as yet be decided. Yet it may humanly speaking be right to entertain a certain degree of belief in them on inductive or other grounds: a logic which proposes to justify such a degree of belief must be prepared actually to go against formal logic; for to a formal truth formal logic can only assign a belief of degree 1. [...] This point seems to me to show particularly clearly that human logic or the logic of truth, which tells men how they should think, is not merely independent of but sometimes actually incompatible with formal logic. ${ }^{90}$
\end{abstract}

61 This passage is quite astonishing. Among all things, Ramsey comes close to stating the problem of omniscience which is linked with the principle of epistemic closure: ${ }^{91}$ it is of course not true that, although one knows the axioms of, say, Peano Arithmetic, therefore one knows all arithmetical truths which follow from them. Some, such as Goldbach's conjecture, are simply not yet decided, ${ }^{92}$ and Ramsey argues that there could situations where one ought to be ready to assign to arithmetical truths a partial belief less than one and thus to go against formal logic. (Although Ramsey does not draw explicitly this inference, his remarks also imply that one has to be ready to go against subjective probability theory.) The conclusion here seems to be this: what is irrational for a perfect, ideal agent may very well be rational for an agent with limited cognitive capacities.

In the second passage, Ramsey considers possible answers to the question "What is meant by saying that it is reasonable for a man to have such and such a degree of belief in a proposition?":

European Journal of Pragmatism and American Philosophy, IV-2 | 2012 
But fourthly it need mean none of these things; for men have not always believed in scientific method, and just as we ask 'But am I necessarily reasonable?,' we can also ask 'But is the scientist necessarily reasonable?' In this ultimate meaning it seems to me that we can identify reasonable opinion with the opinion of an ideal person in similar circumstances. What, however, would this ideal person's opinion be? as has previously been remarked, the highest ideal would be always to have a true opinion and be certain of it; but this ideal is more suited to God than man. ${ }^{93}$

'variable hypothetical,' which actually stands at the heart of his 'human logic.' To see why
he needed this new notion, it suffices that we look at 'general propositions' in their
simplest form:

$$
x \phi(x){ }^{\oplus} \psi(x)
$$

68 In "Facts and Propositions," Wittgenstein's Tractatus, according to which one reads the universal quantifier, " $x \phi(x)$," as a conjunction :

“ $\phi(a) \wedge \phi(b) \wedge \phi(c) \wedge \ldots$

and the existential quantifier, $\$ x \phi(x)$, as a disjunction:

$\phi(a) \vee \phi(b) \vee \phi(c) \vee \ldots$

European Journal of Pragmatism and American Philosophy, IV-2 | 2012 
Thus, a proposition such as 'All men are mortal':

$$
\text { “ } x \phi(x){ }^{\oplus} \psi(x)
$$

has to be interpreted likewise as a logical product, and Wittgenstein assumed at 4.2211 and 5.535 that these sums and products can also be infinite. ${ }^{100}$

However, to speak of an infinitely long product or sum does not have much sense within 'human logic.' If the human mind cannot contemplate an infinite object, how could one use it as a "guide to action"?

A belief [...] is a map of neighbouring space by which we steer. It remains such a map however much we complicate it or fill in details. But if we professedly extend it to infinity, it is no longer a map; we cannot take it in or steer by it. Our journey is over before we need its remoter parts. ${ }^{101}$

Thus, Ramsey came to introduce the notion of 'variable hypotheticals': ${ }^{102}$

Variable hypotheticals or causal laws form the system with which the speaker meet the future. [...] Variable hypotheticals are not judgments but rules for judging 'If I meet a $\phi$, I shall regard it as a $\psi$.' This cannot be negated but it can be disagreed with by one who does not adopt it.

These attitudes seem therefore to involve no puzzling idea except that of habit; clearly any proposition about a habit is general. ${ }^{103}$

To see the evolution of Ramsey's thought, one need merely to recall here the point made at the end of section 2, above: according to Ramsey, in 'Facts and Propositions,' for $S$ to believe in ' $p \& q$ ' or ' $p \vee q$ ' means for $S$ to "act in disregard of the possibilities rejected." In that paper, Ramsey explicitly adopted Wittgenstein's reading of the quantifiers, ${ }^{104}$ but he now realizes that this cannot be possible if the set of truth-possibilities is infinite.

The interpretation as 'rules for judging,' above, or 'fount of judgements' ${ }^{105}$ is an adaptation of the reading of universal quantifiers as 'rules for the formation of judgments' or Urteilsanweisungen by Hermann Weyl. ${ }^{106}$ Together with a reading of the existential quantifier as 'judgement abstract' or Urteilsabstrakte, it allows a constructive reading of the two axioms of quantification theory:

“ $x \phi(x){ }^{\oplus} \phi(a)$,

$\phi(a)^{\circledR} \$ x \phi(x)$,

with which Ramsey agreed in a note dating 1929, 'Principles of Finitist Mathematics.'107 The notions are indeed the same, since the point of Weyl's reading of the quantifiers is that they are not reducible to conjunctions and disjunctions, and thus cannot be negated, and this is precisely what Ramsey insisted upon:

[...] when we assert a causal law we are asserting not a fact, not an infinite conjunction, nor a connection of universals, but a variable hypothetical which is not strictly a proposition at all, but a formula from which we derive propositions. ${ }^{108}$

Thus, variable hypotheticals are rules or schemata, not propositions, they are therefore not assessable in terms of truth and falsity, so Ramsey's conception is, contrary to Hookway's claim quoted above, thoroughly non 'representational.'

There are many points worth discussing at this stage, for example, Peter Geach's 'Frege point,' ${ }^{109}$ against which this conception seems to be running afoul. For the purposes of this paper, that Wittgenstein abandoned his earlier view of the quantifiers in terms of conjunctions and disjunctions in favour of the very similar conception of 'hypotheses' is something one can agree upon, ${ }^{110}$ and my claim is simply that this may indeed be the result of conversations with Ramsey in 1929. One can illustrate the point with help of a number of passages, such as this one:

European Journal of Pragmatism and American Philosophy, IV-2 | 2012 
A hypothesis goes beyond immediate experience.

A proposition does not.

Propositions are true or false.

Hypotheses work or don't work.

A hypothesis is a law for constructing propositions, and the propositions are instances of this law. If they are true (verified), the hypothesis works; if they are not true, the hypothesis does not work. Or we may say that a hypothesis constructs expectations which are expressed in propositions and can be verified or falsified. ${ }^{111}$

As far as foundations of mathematics are concerned, the introduction of variable hypotheticals forms part of Ramsey's late move towards intuitionism or finitism, ${ }^{112}$ but the point of my paper is not to examine the repercussions on his philosophy of mathematics of the introduction of a similar notion by Wittgenstein, even though, as I have already mentioned, he stood probably closer to Brouwer's intuitionism in the Tractatus $^{13}$ and that abandoning his earlier view of the quantifiers may just be a matter of detail; it did not cause any major shift away from the positions of the Tractatus on mathematics. ${ }^{114}$ Nevertheless, I think that it is certainly worth noticing that the introduction of 'variable hypotheticals' in the context of human logic has nothing to do with issues about foundations of mathematics; it is an argument of a pragmatic nature, whose premises are already contained in the discussion of 'human logic' in "Truth and Probability" as well as in the pragmatic rectification of the Tractatus in "Facts and Propositions. ${ }^{115}$ The issue is thus not limited to the infinite case at all. ${ }^{116}$ This much comes up in a passage from "General Propositions and Causality" where Ramsey tackles the issue of praise that he already placed at the centre of 'human logic' - one sees here the deep connexion with "Truth and Probability":

[Variable hypotheticals] form an essential part of our mind. That we think explicitly in general terms is at the root of all praise and blame and much discussion. We cannot blame a man except by considering what would have happened if he had acted otherwise, and this kind of unfulfilled conditional cannot be interpreted as a material implication, but depends essentially on variable hypotheticals. ${ }^{117}$

Ramsey's reasoning here appears to be that when deliberating - or, to speak in the proper jargon: when making a 'choice under uncertainty' - we ask ourselves what will happen if we do this or that and we can answer in two ways: either we have a definite answer of the form 'If I do $p$, then $q$ will result' or we assign a degree of probability: 'If I do $p$, then $q$ will probably result.' In the first case, 'If I do $p$, then $q$ will result,' we have a material implication which can be treated as the disjunction 'Not-p or $q$,' which only differs from ordinary disjunctions because we are not trying to find out if it is a true proposition: in acting we will make one of the disjuncts true. In the second case, 'If I do $p$, then $q$ will probably result,' we are not thinking in terms of 'Not-p or $q$ ' anymore. As Ramsey put it:

Here the degree of probability is clearly not a degree of belief in 'Not- $p$ or $q$,' but a degree of belief in $q$ given $p$, which is evidently possible to have without a definite degree of belief in $p, p$ not being an intellectual problem. And our conduct is largely determined by these degrees of hypothetical belief. ${ }^{118}$

81 The pragmatic nature of Ramsey's train of thought should by now be obvious, so one may ask if there is any trace of this in Wittgenstein's moves away from the doctrines of the Tractatus in 1929, over and above the above change of mind on quantifiers. The idea is, simply, that if Ramsey's introduction of variable hypotheticals primarily motivated not by considerations concerning the foundations of mathematics but by the above pragmatic train of thoughts, then there should be a trace of it in Wittgenstein. It is already visible in 
the passage on 'hypotheses' quoted above, where the context is obviously not the foundations of mathematics, I shall endeavour to show this further with help of passages from the early Middle Period.

Recall that an essential part of the 'static' conception of the Tractatus was the requirement that proposition and state of affairs must have the same logical multiplicity for one to represent the other:

4.04 - In a proposition there must be exactly as many distinguishable parts as in the situation that it represents.

The two must possess the same logical (mathematical) multiplicity.

In manuscripts from 1929 and in the Philosophical Remarks, this conception becomes 'dynamic':

Language must have the same multiplicity as a control panel that sets off the actions corresponding to its propositions [...] Just as handles in a control room are used to do a wide variety of things, so are the words of language that corresponds to the handles. ${ }^{119}$

This point is made in the context of a discussion of the role of intention in language, and that may explain why it has been hitherto unnoticed that the 'dynamic' conception expressed here is new, it has no source in the picture theory of the Tractatus. The point is also contained in remarks such as this:

Understanding is thus not a particular process; it is operating with a proposition. The point of a proposition is that we should operate with it. (What I do, too, is an operation. $)^{120}$

It would be an exegetical blemish simply to assume that this new 'dynamic' view was 'divined' by Wittgenstein independently of any influence, while one can simply see here the impact of Ramsey's pragmatist critique of the Tractatus, and his concomitant view, quoted above, that

the meaning of a sentence is to be defined by reference to the actions to which asserting it would lead.

Furthermore, a 'variable hypothetical' or an 'hypothesis' may just be seen as an 'handle in a control room,' precisely because the handles don't 'represent' anything: they set off actions. It is often said that the move to the later Wittgenstein involved an interest in moods other that indicative, but as we can see here, it is deeper than that, it reflects a change in his conception of the meaning of declarative sentences to begin with.

In order for this point to become obvious, I needed to take a very long detour into the interpretation of Ramsey's philosophy, a prerequisite to any evaluation of the impact of his discussions with Wittgenstein on his evolution from the Tractatus to his later positions. I hope that this detour will have helped to shed light on this point, in a manner that does justice to both philosophers. 


\section{BIBLIOGRAPHY}

ACERO J. J., (2005), “Mind, Intentionality, and Language. The Impact of Russell's Pragmatism on Ramsey," in Frápolli (2005).

BAIN A., (1859), The Emotions and the Will, London, Parker.

BRAIthWAite R. B., (1933a), “Philosophy,” in H. Wright (ed.), University Studies. Cambridge 1933, London, Ivor Nicholson \& Parker.

BRAithwaite R. B., (1933b), “The Nature of Believing," Proceedings of the Aristotelian Society 33.

CARNAP R., (1952), The Continuum of Inductive Methods, Chicago, University of Chicago Press.

CARNAP R., \& W. STEGMÜLLER, (1959), Induktive Logik und Warscheinlichkeit, Vienna, Springer.

DAVIDSON D., \& P. sUPPES, (1956), “A Finitistic Axiomatisation of Subjective Probability Theory and Utility," Econometrica 24.

DAVIDSON D., SUPPES P., \& S. SIEGEL, (1957), Decision Theory, Stanford, Stanford University Press.

DAVIDSON D., (2004), Problems of Rationality, Oxford, Clarendon Press.

DE FINETTI B., (1937), “La prévision: ses lois logiques, ses sources subjectives," Annales de l'Institut Poincaré 7.

FRÁPOLli M. J., (ed.), (2005), F. P. Ramsey. Critical Reassessments, London, Continuum.

GalavotTi M. C., (ed.), (2006), Cambridge and Vienna. Frank P. Ramsey and the Vienna Circle, Dordrecht, Springer.

GEACH P. T., (1965), “Assertion,” Philosophical Review 74.

GLOCK H.-J., (2005), “Ramsey and Wittgenstein: Mutual Influences,” in Frápolli (2005).

GOodman N., (1979), Fact, Fiction and Forecast, Cambridge, Harvard University Press.

GRICE P., (1986), "Reply to Richards," in R. E. Grandy \& R Warner (eds.), Philosophical Grounds of Rationality, Oxford, Clarendon Press.

HоOKWAY C., (2005), “Ramsey and Pragmatism,” in Frápolli (2005).

Howson C., (2005), “'Ramsey’s Big Idea,” in Frápolli (2005).

KENNY A., (1973), Wittgenstein, Harmondsworth, Penguin Books.

KEYNES J. M., (1933), Essays in Biography, London, MacMillan.

KEYNES J. M., (1973), A Treatise on Probability, London, MacMillan.

KEYNES J. N., (1989), Studies and Exercises in Formal Logic, London, MacMillan.

KIENZLER W., (1997), Wittgensteins Wende zu seiner Spätphilosophie 1930-32, Frankfurt, Suhrkamp.

MAJER U., (1988), “Zu einer bemerkenswerten Differenz zwischen Brouwer und Weyl,” in W. Deppert et al. (eds.), Exact Sciences and their Philosophical Foundations, Frankfurt, Peter Lang. 
MAJER U., (1989), “Ramsey's Conception of Theories: An Intuitionistic Approach,” History of Philosophy Quarterly 6.

MAJER U., (1991), “Ramsey's Theory of Truth and the Truth of Theories: A Synthesis of Pragmatism and Intuitionism in Ramsey's Last philosophy," Theoria 57.

MARION M., (1995), “Wittgenstein and Finitism," Synthese 105.

MARION M., (1996), “Wittgenstein and Ramsey on Identity," in J. Hintikka (ed.), From Dedekind to Gödel, Dordrecht, Kluwer.

MARION M., (1998), Wittgenstein, Finitism, and the Foundations of Mathematics, Oxford, Clarendon Press.

MARION M., (2003), “Wittgenstein and Brouwer," Synthese 137.

MARION M., (2008), "Brouwer on Hypotheses and the Middle Wittgenstein," in M. van Atten, P. Boldini, M. Bourdeau \& G. Heinzmann (eds.), One Hundred Years of Intuitionism 1907-2007, Basel, Birkhäuser, 96-114.

MCGUINNESS B. F., (2006), “Wittgenstein and Ramsey,” in Galavotti (2006).

MOORE G. E., (1904), “Philosophy of the United Kingdom,” Archiv für Systematische Philosophie, 10.

MOORE G. E., (1959), Philosophical Papers, London, Allen \& Unwin.

OGDEN C. K., \& I. A. Richards, (1923), The Meaning of Meaning, London, Kegan Paul, Trench, Trubner $\&$ Co.

PARTRIDGE F., (1981), Memories, London, Victor Gollancz.

PEIRCE C. S., (1923), Chance, Love and Logic, M. R. Cohen (ed.), New York, Harcourt, Brace \& Co.

PEIRCE C. S., (1931-35), Collected Papers, 5 vols., Cambridge MA, The Belknap Press.

PEIRCE C. S., (1992), The Essential Peirce. Selected Philosophical Writings. Volume 1 (1867-1893), Bloomington \& Indianapolis, Indiana University Press.

RAMSEY F. P., (1923), “Tractatus Logico-Philosophicus by Ludwig Wittgenstein,” Mind 32.

RAMSEY F. P., (1924), “The Meaning of Meaning. By C. K. Ogden \& I. A. Richards,” Mind 33, 108-9.

RAMSEY F. P., (1990), Philosophical Papers, Cambridge, Cambridge University Press.

RAMSEY F. P., (1991a), Notes on Philosophy, Probability and Mathematics, Naples, Bibliopolis.

RAMSEY F. P., (1991b), On Truth, Dordrecht, Kluwer.

RAMSEY F. P., (2010), “The Ramsey Notes on Time and Mathematics,” in N. Venturinha (ed.), Wittgenstein after his Nachlass, Basingstoke, Palgrave-MacMillan.

RORTY R., (1961), “Pragmatism, Categories and Language,” Philosophical Review 70.

RUSSEll B., (1919), “On Propositions: What they Are and What they Mean,” Aristotelian Society, Supplementary Volume, 2.

RUSSELL B., (1921), Analysis of Mind, London, Allen \& Unwin.

RUSSELl B., (1959), My Philosophical Development, London, Allen \& Unwin.

SAHLIN N.-E., (1990), The Philosophy of F. P. Ramsey, Cambridge, Cambridge University Pres"

SAHLIN N.-E., (1990), “'He is no good for my work.' On the Philosophical Relations Between Ramsey and Wittgenstein," Poznan Studies in the Philosophy of the Sciences and the Humanities, 51. 
SAHLIN N.-E., (1995), “On the Philosophical Relations between Ramsey and Wittgenstein,” in J. Hintikka \& K. Puhl (eds.), The British Tradition in 20th Century Philosophy. Proceedings of the 17th International Wittgenstein-Symposium, Vienna, Hölder-Pichler-Tempsky.

SCHILlER F. C. S., (1902), “Axions as Postulates," in H. Sturt (ed.), Personal Idealism: Philosophical Essays by Eight Members of the University of Oxford, London, Macmillan.

SUPPES P., (1956), "The Role of Subjective Probability and Utility in Decision-Making," in

I. Neyman (ed.), Proceedings of the 3rd Berkeley Symposium on Mathematics, Statistics and Probability, Los Angeles, University of California Press.

TAYLOR G., (2006), “Frank Ramsey - A biographical Sketch,” in Galavotti (2006).

THAYER H. S., (1981), Meaning and Action. A Critical History of Pragmatism, 2nd ed., Indianapolis, Hackett.

voN Wright G.-H., (1982), Wittgenstein, Oxford, Blackwell.

WEYL H., (1998), "On the New Foundational Crisis in Mathematics," in P. Mancosu (ed.), From

Brouwer to Hilbert. The Debate on the Foundations of Mathematics in the 1920s, Oxford, Oxford University Press.

WitTGENSTEIN L., (1961), Tractatus Logico-Philosophicus, London, Routledge \& Kegan Paul.

WitTGENSTEIN L., (1973), Letters to C. K. Ogden, Oxford/London, Blackwell/Routledge \& Kegan Paul.

WITTGENSTEIN L., (1975), Philosophical Remarks, Oxford, Blackwell.

WitTGENSTEIN L., (1980), Wittgenstein's Lectures. Cambridge 1930-32, Totowa NJ, Rowman \& Littlefield.

Wittgenstein L., (2003), Ludwig Wittgenstein. Public and Private Occasions, Totowa NJ, Rowman \& Littlefield.

WitTGenSteIN L., (2009), Philosophical Investigations, 4th edition, Oxford, Wiley-Blackwell.

\section{NOTES}

1. For the first occurrence of this sort of move, see Rorty 1961.

2. I was able to consult a typed copy of Rhees' notes at the von Wright \& Wittgenstein Archives housed in the Department of Philosophy of the University of Helsinki.

3. Sahlin (1997: 65).

4. Schiller was indeed the first in Britain to describe his own philosophy as 'pragmatist' in "Axioms as Postulates" (1902), a paper that G. E. Moore described as "utterly worthless" (1904: 259), while Peirce considered it "most remarkable" (1931-35: 5.414). He figures significantly in the sources to Lady Welby's 'significs,' and they are both discussed C. K. Ogden \& I. A. Richards' The Meaning of Meaning, e.g., at (1923: 272f.). They also get a mention in Russell's My Philosophical Development (1959: 14). A proper assessment of their legacy falls outside the scope of this paper.

5. Ramsey (1990: 51).

6. Thayer (1981: 313) already expressed the hope that one would clarify the links between Ramsey, Wittgenstein and American pragmatism, but there are only an handful of studies such as Glock 2005, McGuinness 2006, and Sahlin 1995, 1997, as well as lengthy discussions in Kienzler 1997 and Marion 1998.

7. See von Wright 1982 and Sahlin 1995, 1997.

8. See Sahlin (1997: 74-5 \& 82-3, n. 48). 
9. One is eager to quote here Paul Grice (1986: 62), on J. L. Austin's treatment of sense-data theories such as H. H. Price's in Sense and Sensibilia: “So far as I know, no one has ever been the better for receiving a good thumping, and I do not see that philosophy is enhanced by such episodes. There are other ways of clearing the air besides nailing to the wall everything in sight." 10. For an overview of Ramsey's life, see Taylor 2006.

11. See Wittgenstein (1973: 8).

12. Wittgenstein (1973: 78).

13. Quoted in Sahlin (1997: 64), and Taylor (2006: 5).

14. Wittgenstein (1973: 78).

15. Ramsey 1923.

16. Today, on the other hand, any non-pledged philosopher mentioning Wittgenstein has to face a group of commentators reminiscent of the Bandar-log in Kipling's Jungle Book, starting "furious battles over nothing among themselves."

17. See Marion 1993.

18. See the testimony of Frances Partridge, 'The Death of a Philosopher,' in Partridge (1981: 169f.).

19. Quoted in McGuinness (2006: 23).

20. Wittgenstein (2003: 15-7).

21. See Wittgenstein 2010 , edited by Nuno Venturinha.

22. If my comments at the very end of htis section on the normative conception of logic are on the right tracks, then an example of this sort of mistake is found in Hanjo Glock's appeal to Wittgenstein's normative view of logic in Glock (2005: 59), in order to contrast it with a "purely causal and behaviorist" conception he attributes to Ramsey. (On this last point, I hope to have shown in section 2 that Ramsey's views are not to be conflated with those of Russell and ogden \& Richards.)

23. These papers were grouped under that heading in R. B. Braithwaite's original edition of Ramsey's collected papers in 1931.

24. Majer 1989, 1991.

25. See Marion 1995 and (1998: chapters 4-5).

26. McGuinness (2006: 24-5).

27. See Ramsey (1991b : 33-4), where the notion discussed below in section 4 under the name of 'variable hypothetical' is already occurring in 1928.

28. Marion 2003, 2008.

29. See, for example, Kienzler (1997: 75-6).

30. This is strictly speaking incorrect as these discussions only took place between January 1929, when Wittgenstein came back to Cambridge, and January 1930, when Ramsey died.

31. Wittgenstein (2009: 4).

32. Wittgenstein (2009: § 81).

33. Ramsey (1991a: 277).

34. Quotations from the Tractatus in this paper refer to the Pears \& McGuinness translation in Wittgenstein 1961.

35. Ramsey (1923: 471).

36. Ramsey (1923: 471).

37. Ramsey (1990: 48).

38. Ramsey (1990: 48).

39. Braithwaite (1933a: 1).

40. For a detailed analysis of Ramsey's debt to Russell's theory, see the excellent paper by Juan José Acero 2005. The discussion of Ramsey in this section is heavily indebted to this paper.

41. Wittgenstein (1975: §§ 20-38).

42. Russell (1919: 31).

43. Russell (1921: 197). 
44. Russell (1921: 198).

45. Ramsey 1924. For what differences they perceived between their theory and Russell's, see Ogden \& Richards (1923: 141-2 n.).

46. Russell (1921: 197). It is noteworthy that Russell attributes the view in a footnote to the behaviourist J. B. Watson.

47. Wittgenstein (1975: § 21). Wittgenstein's critique is discussed, for example, in Kenny (1973: 123-30) as initiating one of the moves away from the picture theory of the Tractatus.

48. In his review of Ogden \& Richards 1923, Ramsey (1924: 109) praised the appendix on Peirce. See Ogden \& Richards (1923: 432-44). It is quite possible that it is through them that Ramsey first learned about Peirce.

49. Peirce (1992: 114). This paper and 'How to Make our Ideas Clear' were reprinted in a collection of Peirce's essays, Chance, Love and Logic (1923) that Ramsey read. This key idea is repeated elsewhere, e.g., in the 'Lectures on Pragmatism' (1903), where Peirce wrote that "belief consists mainly in being deliberately prepared to adopt the formula believed in as the guide to action" (1931-35: 5.27).

50. Peirce (1992: 131). Again, the idea is repeated elsewhere, e.g., in 'Elements of Logic,' where Peirce wrote that "the inferential process involves the formation of a habit. For it produces a belief, or opinion; and a genuine belief, or opinion, is something on which a man is prepared to act" (1931-35: 2.148).

51. Incidentally, these ideas were not exactly new to Peirce and can be found already in Alexander Bain, who thought that "belief has no meaning, except in reference to our actions." See Bain (1859: 372). The point was first made by Braithwaite, who also showed that Bain recanted later on (Braithwaite 1933b: 33). One may even trace the origin of this sort of thinking to David Hume, according to whom, in Enquiry Concerning Human Understanding, Sec. V, part I, § 36: "custom" or "habit" is "the great guide of human life."

52. Ramsey (1991a: 278).

53. Ramsey (1990: 153).

54. Ramsey (1990: 159).

55. Ramsey (1990: 46).

56. I owe the point to Acero (2005: 36).

57. The interpretation proposed in the next section is not entirely new, it is largely based on Nils-Eric Sahlins' The Philosophy of F. P. Ramsey (1990).

58. Hookway (2005: 186).

59. Howson (2005: 157). This philosophical idea sets him apart from other early contributors to the topic such as Bruno de Finetti. See de Finetti 1937.

60. Ramsey (1990: 87).

61. Ramsey (1990: 99-101).

62. Peirce (1992: 161). Ramsey's use of Peirce's distinction between 'explicative' and 'ampliative' arguments was motivated by the fact that he used the expression 'inductive logic' as a synonym for 'logic of truth,' while he believed that distinction between the latter and the 'logic of consistency' does not overlap the traditional distinction between 'deductive' and 'inductive' logic. The reason is clear from his definition of the validity of an inference, see Ramsey (1990: 82).

63. Ramsey (1990: 82).

64. Ramsey's reasons are pretty much standard today, see Ramsey (1990: 81-2).

65. Ramsey (1990: 82).

66. Suppes 1956.

67. See de Finetti 1937.

68. Davidson (2004: 154).

69. Ramsey (1990: 78).

70. Ramsey (1990: 87). 
71. For example, at Keynes (1973: 15-6).

72. Stated at Keynes (1973: 121).

73. Ramsey (1990: 85).

74. Howson (2005: 145).

75. Ramsey (1990: 80).

76. Ramsey (1990: 89-90).

77. See Ramsey (1990: 84): "in a sense we may say that the two interpretations [frequentist and Bayesian] are the objective and subjective aspects of the same inner meaning, just as formal logic can be interpreted objectively as a body of tautology and subjectively as the laws of consistent thought."

78. Ramsey (1990: 87).

79. Ramsey (1990: 90).

80. Ramsey (1990: 92).

81. Ramsey's use of 'inductive logic' is idiosyncratic, but carries potentially confusing connotations of Carnap's project of an inductive logic, e.g., in Carnap 1952 and Carnap \& Stegmüller 1959. See footnote 62 above.

82. Ramsey (1990: 94). This idea had been put forward by Ramsey already in 1922, in a paper to the Apostles, see Ramsey (1991a: 301).

83. Ramsey even began to doubt in 1929 that this use of 'reasonable' is appropriate. See Ramsey (1990: 101). This procedure would itself be inductive, but this 'induction on inductions' is not viciously circular - for obvious reasons - and it would proceed by simple enumeration and thus be finite.

84. As stated, e.g., in Chapter 3, of Goodman 197.

85. For example, at Ramsey (1990: 87).

86. Ramsey (1990: 87).

87. Ramsey (1990: 89).

88. Keynes (1933: 300-1).

89. Ramsey (1990: 79). Decision theory usually involves an infinite set of alternatives and an infinity of probability combinations, see, e.g., Davidson, Suppes \& Siegel (1957: 7-8).

90. Ramsey (1990: 87).

91. This is the principle that says that if I know that $p$, and I know that $p$ implies $q$, then I know that $q$. This is, of course a mere epistemic variant of the principle of deductive closure.

92. Recall that Ramsey published a result which is a partial solution to the Entscheidungsproblem. In this passage, he clearly speaks of decidability in these terms.

93. Ramsey (1990: 89-90).

94. Ramsey (1990: 90, n. 2).

95. Ramsey (1990: 90).

96. Ramsey (1990: 91).

97. Ramsey (1990: 92).

98. Ramsey (1990: 93-4).

99. Ramsey (1990: 48-9).

100. Ramsey used very this point in proposing a new definition of 'predicative function' in 1925 in "The Foundations of Mathematics"; see Ramsey (1990: 170f.). Wittgenstein opposed that move, and came back to it in his notebooks, thus creating the impression that there was no common grounds between him and Ramsey. But, as one can see here, Ramsey also abandoned these views in 1929 and it is plainly exegetically wrong not to take this into account.

101. Ramsey (1990: 146).

102. The expression appears to originate in John Neville Keynes's Studies and Exercises in Formal Logic (1889).

103. Ramsey (1990: 149). 
104. Ramsey (1990: 48-9).

105. Ramsey (1991a: 235).

106. Weyl's reading of the quantifiers was first presented in "Über die neue Grundlagenkrise der Mathematik" in Weyl 1921; see Weyl (1998: 97-8). For an analysis of the distinction between Brouwer and Weyl on quantification, see Majer 1988.

107. Ramsey (1991a: 197-202).

108. Ramsey (1990: 159).

109. Geach (1965: 459).

110. See, for example, the testimony of von Wright (1982: 151 n. 28) or Wittgenstein's avowal in his classes at Wittgenstein (1980: 119), or Moore (1959: 298). I have argued, however, in Marion 2008 that Wittgenstein got the term 'hypothesis' from Brouwer's 1928 lecture in Vienna. This does not imply that he realized his mistake hearing Brouwer, simply that he used instead of Ramsey's 'variable hypotheticals' or Weyl's 'Urteilsanweisungen,' a term borrowed from Brouwer. It is also important to note here that Brouwer uses the term while discussing the visual field, not foundations.

111. Wittgenstein (1980: 110).

112. The view that Ramsey switched to intuitionism under the influence of Weyl on quantification (among other things) was first propounded by Ulrich Majer $(1989,1991)$. It is also acknowledged in Sahlin (1990: chaps. 5 \& 6) and further developed in Marion 1995 and Marion (1998, chap. 4), in relation to Wittgenstein.

113. Again, see Marion 2003, 2008.

114. I have discussed the relevant passages in Marion 1995, and in Marion (1998: chaps.4-6).

115. Conflating the pragmatic argument with issues in the foundations of mathematics is, I think, the mistake made by McGuinness in the passage quoted above in section 1, that prevents him from properly assessing Ramsey's impact on Wittgenstein: since Wittgenstein's position on foundations does not change, McGuinness cannot see that he learned anything from Ramsey.

116. As far as the infinite case is concerned, there is a clear link with finitism in the foundations of mathematics, which is clearly expressed in 'General Propositions and Causality,' as well, of course, as in other notes from 1929, such as Ramsey (1990: 160): "So too there may be an infinite totality, but what seems to be propositions about it are again variable hypotheticals and 'infinite collections' is really nonsense."

117. Ramsey (1990: 153-4).

118. Ramsey (1990: 153-4). One could pursue the line of thought here using Ramsey's own example of a man deliberating if he is to eat a cake or not (1990: 154-5), and this brings us back to his famous example of the chicken that believes a certain caterpillar to be poisonous (1990: 40).

119. Wittgenstein (1975: § 13).

120. Wittgenstein (1979: 167).

\section{ABSTRACTS}

In this paper, I examine the transmission of some ideas of the pragmatist tradition to Wittgenstein, in his 'middle period,' through the intermediary of F. P. Ramsey, with whom he had numerous fruitful discussions at Cambridge in 1929. I argue more specifically that one must first come to terms with Ramsey's own views in 1929, and explain how they differ from views 
expressed in earlier papers from 1925-27, so a large part of this paper is devoted to this task. One is then in a better position to understand the impact of Ramsey's astute critique of Wittgenstein's Tractatus Logico-Philosophicus in conjunction with his pragmatism, and explain how it may have set into motion the 'later' Wittgenstein. I then argue that Ramsey introduced his notion of 'variable hypothetical' as a rule, not a proposition, on pragmatist grounds and that Wittgenstein picked this up in 1929, along with a more 'dynamic' view of meaning than the 'static' view of the Tractatus, and that this explains in part Wittgenstein's turn to his 'later philosophy.'

\section{AUTHOR}

\section{MATHIEU MARION}

Université du Québec à Montréal

marion.mathieu[at]uquam.ca 